\title{
REVIEW
}

\section{CARBOIDRATOS FIBROSOS E NÃO FIBROSOS NA DIETA DE RUMINANTES E SEUS EFEITOS SOBRE A MICROBIOTA RUMINAL}

\author{
Vinicius da Silva Oliveira ${ }^{1}$, José Adelson Santana Neto ${ }^{2}$, Roberta de Lima Valença ${ }^{3}$, Barbará \\ Cristina Dantas da Silva ${ }^{1}$, Ana Caroline Pinho dos Santos ${ }^{1}$
}

\section{RESUMO}

O objetivo da presente revisão é avaliar a concentração de carboidratos fibrosos e não fibrosos na dieta de ruminantes e os efeitos sobre a microbiota ruminal. Os carboidratos são as biomoléculas mais abundantes da natureza e exercem função estrutural e energética, sendo a principal fonte de energia para ruminantes. Eles podem ser classificados de acordo com sua estrutura e função, assim como do ponto de vista nutricional, o qual os dividem em carboidratos fibrosos e não fibrosos. Os carboidratos são fermentados no rúmen pela ação da flora microbiana, a qual tem seu desenvolvimento afetado diretamente pelo tipo de carboidrato, pois os microrganismos ruminais apresentam especificidade quanto ao substrato que fermentam. Além disso, a taxa de fermentação dos carboidratos no rúmen altera as condições do ambiente ruminal, afetando diretamente o desenvolvimento dos microrganismos nele presentes. Os carboidratos não fibrosos apresentam alta taxa de fermentação, levando à redução do $\mathrm{pH}$ ruminal e influenciando o desenvolvimento da flora ruminal; já os carboidratos não fibrosos apresentam baixa taxa de fermentação e estimulam a ruminação, bem como a maior salivação do animal, o que auxilia no tamponamento do $\mathrm{pH}$ do rúmen. Por essa razão, o equilíbrio no fornecimento de carboidratos fibrosos e não fibrosos é importante para manter o ambiente ruminal estável. O principal produto da fermentação ruminal dos carboidratos são os ácidos graxos voláteis (AGVs), que são utilizados pelos ruminantes como sua principal fonte energética.

Palavras-chave: AGVs, flora microbiana, rúmen

\section{INTRODUÇÃO}

Os carboidratos, ou hidratos de carbono, são as biomoléculas mais abundantes na natureza e têm função estrutural ou energética, além de fazerem parte da estrutura dos ácidos nucleicos (RNA e DNA, formando os monossacarídeos ribose e desoxirribose, respectivamente). Eles são definidos quimicamente como poli-hidróxi-cetonas (cetoses) ou poli-hidróxi-aldeídos (aldoses), que são compostos orgânicos formados com no mínimo três átomos de carbono, os quais possuem um radical hidroxila em cada átomo com exceção da carbonila primária, que possui grupamento aldeídico, ou a carbonila secundária, que possui grupamento cetônico (NELSON e COX, 2002).

Os carboidratos são formados por monômeros, que se unem por meio de ligações covalentes, denominadas glicosídicas do tipo alfa ou beta. Essas ligações ocorrem entre um grupo hidroxila de um carboidrato com o grupo hidroxila de outro ou de um álcool (HALL, 2014).

Os carboidratos constituem de 70 a $80 \%$ da dieta dos ruminantes, pois a base da alimentação desses animais são as plantas forrageiras, as quais são formadas principalmente por carboidratos (BERCHIELLI et al., 2011).

A oxidação dos carboidratos é a principal fonte de energia para os animais, em razão do elevado teor de energia que eles possuem. Nos ruminantes, os carboidratos são fermentados por meio da ação da flora ruminal, e os produtos dessa fermentação (AGVs) são utilizados como fonte de energia pelo hospedeiro para gerar produtos de origem animal, como carne e leite (ALVES et al., 2009).

\footnotetext{
*Artigo recebido em: 22/12/2015

${ }^{1 .}$ Universidade Federal da Bahia.

2. Universidade Federal da Paraíba.

3. Universidade Estadual Paulista Julio Mesquita Filho - UNESP/Jaboticabal.

*Corresponding author: E-mail: viny_oliveira@yahoo.com.br.
} 
Segundo Kozloski (2002), os AGVs representam a principal fonte de energia para os ruminantes, mantendo de 75 a $80 \%$ da energia originalmente contida nos carboidratos.

Os microrganismos ruminais não têm a capacidade de aproveitarem lipídios como fonte de energia, por se tratarem de moléculas com baixo teor de oxigênio, e eles necessitam reduzir o substrato para utilizá-lo como fonte energética. Desse modo, os carboidratos são a principal fonte de energia para flora ruminal, sendo utilizados para síntese de proteína microbiana (NRC, 1996).

A disponibilidade, estrutura, taxa de passagem e fermentação dos carboidratos presentes no rúmen influenciam o seu aproveitamento pela flora microbiana, refletindo no desenvolvimento da microbiota ruminal. Os microrganismos ruminais apresentam especificidade quanto ao substrato que degradam, portanto, a dieta exerce influência sobre o tipo de microrganismo que irá se desenvolver no rúmen (PINA et al., 2010).

Com base no exposto acima, o objetivo desta revisão é abordar os efeitos da concentração de carboidratos fibrosos e não fibrosos na dieta de ruminantes e a influência desses carboidratos na microbiota ruminal.

\section{DESENVOLVIMENTO}

\section{Classificação dos carboidratos}

Os carboidratos podem ser classificados de diversas formas: pelas unidades de monômeros de formação, que os divide em monossacarídeos, dissacarídeos, oligossacarídeos e polissacarídeos; pela função que exercem no tecido da planta, categorizados em: carboidratos estruturais e não estruturais; ou do ponto de vista nutricional, que os classifica em: carboidratos fibrosos e não fibrosos (HALL, 2014).

Os carboidratos fibrosos constituem a parede celular e são responsáveis por darem sustentação ao vegetal; já os carboidratos não fibrosos são armazenados e servem como reserva energética. Os carboidratos fibrosos estão presentes em maior quantidade nas plantas forrageiras (KOZLOSKI, 2002), sendo o principal componente da dieta dos ruminantes.

Dentre os carboidratos fibrosos, encontram-se a hemicelulose, a celulose e a lignina, que não é um carboidrato, e sim um composto fenólico que complexa principalmente a pectina e a hemicelulose, tornando-as indisponíveis. A pectina, apesar de estar presente na estrutura da parede celular da planta, não é um carboidrato fibroso, por ser solúvel em água. Os principais carboidratos não fibrosos são a pectina, o amido, os açúcares solúveis (glicose, frutose, maltose e galactose) e as frutosanas (BRANDI e FURTADO, 2009).

Os mamíferos não produzem enzimas capazes de digerir carboidratos fibrosos, sendo que os ruminantes desenvolveram uma relação simbiótica com os microrganismos aptos para fermentar fibras (OLIVEIRA et al., 2013). Os microrganismos presentes no rúmen são os principais responsáveis pela degradação da fibra.

Em 1962, Annison e Lewis - citando Henneberg e Stohmann (1860) - descreveram com detalhes a degradação dos tecidos de plantas no rúmen. Posteriormente, foi observado que nas áreas erodidas da fibra havia a presença de microrganismos fermentadores. Os principais microrganismos ruminais degradadores de fibra são bactérias celulolíticas e sacarolíticas, que se aderem ao substrato liberando enzimas (celulases) e degradando a fibra (OLIVEIRA et al., 2013).

A fermentação ruminal, que precede a digestão gástrica em ruminantes, converte os componentes estruturais das plantas em formas que possam ser utilizadas pelos animais (SILVA e LEÃO, 1979). Tal como na proteína microbiana, nos AGVs e em algumas vitaminas (SANTANA NETO et al., 2012), também são gerados resíduos oriundos da fermentação microbiana que não podem ser utilizados pelos animais e são perdidos principalmente via eructação, como $\mathrm{CO}_{2}, \mathrm{H}_{2} \mathrm{e}$ $\mathrm{CH}_{4}$.

Os microrganismos ruminais apresentam especificidade quanto ao tipo de substrato que digerem. Manella et al. (2003) afirmaram que dietas à base de forragens possuem maior quantidade de carboidratos estruturais, resultando em maior atividade de bactérias celulolíticas e sacarolíticas. Por outro lado, dietas ricas em amido e/ou proteína favorecem a ação das bactérias amilolíticas e/ou proteolíticas (CHURCH, 1988).

$\mathrm{O}$ tipo de substrato presente no rúmen influencia diretamente o desenvolvimento da população microbiana, alterando os produtos gerados pela fermentação e as condições do ambiente ruminal, pois, a depender da fonte de carboidrato presente na dieta, haverá alterações 
no $\mathrm{pH}$ e disponibilidade de energia e nitrogênio, afetando o desenvolvimento da microbiota ruminal. A síntese de proteína microbiana no rúmen depende de uma faixa de $\mathrm{pH}$ ideal e do fornecimento adequado e sincronizado de energia e nitrogênio para os microrganismos (CAMERON et al., 1991).

Van Soest (1994) afirmou que valores de $\mathrm{pH}$ abaixo de 6,2 aumentam o tempo para colonização da fibra, reduzindo sua degradação. No entanto, bactérias amilolíticas atuam em $\mathrm{pH}$ mais baixo, menor que 5,8, levando a uma faixa de $\mathrm{pH}$ ideal no rúmen entre 5,5 e 7,0 (FURLAN, 2011).

De acordo com Oliveira et al. (2013), dietas ricas em carboidratos de alta fermentação e baixo teor de fibra reduzem o $\mathrm{pH}$, em razão da maior produção de $\mathrm{AGV}$ e ácido lático no ambiente ruminal. Já dietas com alto teor de fibra promovem o aumento do $\mathrm{pH}$, por estimularem a ruminação e, consequentemente, a salivação, diluindo e tamponando o conteúdo ruminal. Microrganismos celulolíticos (algumas espécies de bactérias e protozoários) e bactérias metanogênicas têm baixa tolerância à diminuição dos valores do pH (SLYTER, 1976; WASCHECK et al., 2008).

Segundo Valadares Filho e Pina (2011), dietas com maior proporção de forragem diminuem a concentração de ácidos ruminais quando comparadas àquelas com maior proporção de concentrado - 50 a 100 $\mathrm{mmol} / \mathrm{L}$ de AGVs e 80 a $150 \mathrm{mmol} / \mathrm{L}$ de AGVs, respectivamente. De acordo com Alves et al. (2002), carboidratos não fibrosos aumentam a produção de $\mathrm{AGV}$ e reduzem a concentração de amônia ruminal, maximizando a eficiência energética e aumentando a produtividade animal.

\section{Carboidratos fibrosos}

Os carboidratos fibrosos (CF) são polímeros que participam da composição da parede celular do vegetal. Representados por celulose e hemicelulose, esses carboidratos, juntamente com a pectina e a lignina, são responsáveis por darem sustentação e proteção à planta (CABRAL et al., 2002).

A degradação dos CF no rúmen é influenciada pela organização dos polímeros que os formam e pelas interações entre as pontes de hidrogênio que fazem as ligações entre as cadeias de polímeros. A organização dos polímeros de celulose e hemicelulose e as pontes de hidrogênio dão relativa resistência à estrutura da célula vegetal. Por essa razão, esses carboidratos possuem degradação lenta e parcial, ocupando espaço no trato gastrointestinal dos animais (CABRAL et al., 2002).

A celulose é um homopolissacarídeo constituído por unidades de glicose, ligadas entre si por ligações glicosídicas $\beta-1,4$. Os polímeros de celulose estão distribuídos paralelamente entre si, formando camadas de cobertura de célula vegetal (KOZLOSKI, 2002). Tal disposição confere maior resistência à célula, dificultando, assim, a degradação em nível ruminal, por obstruir $\mathrm{o}$ ataque dos microrganismos degradadores de fibra, fazendo com que a celulose tenha menor aproveitamento por parte do animal (CAMPOS et al., 2002; CARVALHO e PIRES, 2008).

A hemicelulose é constituída principalmente por xiloglucanas, contribuindo com aproximadamente 20-25\% dos constituintes da parede celular da planta (PAIVA et al., 2009). As xiloglucanas se ligam à celulose, à pectina e à lignina por meio de pontes de hidrogênio, formando ligações cruzadas que dão estabilidade à parede celular (WAKABAYASHI, 2000). A disposição cruzada das ligações dos polímeros que formam a hemicelulose dá menor resistência à degradação desse carboidrato em nível ruminal, quando comparado à celulose.

A lignina é um complexo polímero fenólico, formado basicamente por três grupos fenólicos (exercendo tanto função de ácido como de aldeído): ácido p-coumárico, ácido ferúlico e ácido sinápico. A lignina realiza ligações covalentes com os polissacarídeos da parede celular, diminuindo a taxa de degradação ruminal, por formar uma barreira mecânica para a ação dos microrganismos (CAMPOS et al., 2002).

A estrutura e disposição da parede celular do vegetal determina a taxa de degradação e o tipo de microrganismo que se desenvolverá. Os microrganismos degradadores de fibra são bactérias celulolíticas, protozoários e fungos (CARVALHO e PIRES, 2008).

Os CF limitam o desenvolvimento dos microrganismos ruminais por causa da baixa assimilação do nitrogênio disponível na proteína microbiana e por possuírem alta degradabilidade dos compostos nitrogenados e baixa fermentação dos carboidratos (DETAMANN et al., 2005). 


\section{Classificação dos carboidratos fibrosos do ponto de vista analítico e suas implicações no consumo e desempenho de ruminantes}

A predição do consumo em ruminantes é um dos fatores de maior importância para conhecer a qualidade da dieta, visto que o consumo é o que limitará o nível de produtividade e produção (ZANINE e MACEDO JÚNIOR, 2007). Um dos principais fatores de regulação do consumo em ruminantes é o teor de fibra e o volume da dieta ingerida.

"Fibra" é um termo apenas de definição nutricional, relacionado com $\mathrm{o}$ método de análise utilizado para sua determinação (MACÊDO JÚNIOR et al., 2007). Segundo Mertens (1997), a fibra não é uma entidade química distinta, e sim um agregado de compostos, portanto, sua composição química é dependente do método laboratorial utilizado. Apesar de não ser uma entidade química específica, a fibra está relacionada aos componentes da parede celular do vegetal, sendo assim, o método de determinação da fibra tem de ser capaz de predizer a constituição desses componentes, que são: a hemicelulose, a celulose, a lignina, o nitrogênio associado à parede celular, os minerais e a sílica.

Visando à obtenção de um conhecimento mais detalhado das frações que constituem a fibra, Van Soest (1965) propôs um método de avaliação baseado no uso de reagentes específicos, os detergentes (SILVA e QUEIROZ, 2009). Por meio do uso de soluções de detergentes neutro e ácido, as quais são utilizadas para determinar a fibra insolúvel em detergente neutro (FDN) e a fibra insolúvel em detergente ácido (FDA), respectivamente, percebeu-se que é possível separar o conteúdo celular (proteína, pectina, carboidratos solúveis, gorduras e demais componentes solúveis em água) dos componentes da parede celular (hemicelulose, celulose, lignina, proteína complexada e/ou constituinte da parede celular, sílica e minerais). A solução de FDN solubiliza o conteúdo celular, permanecendo no resíduo a hemicelulose, a celulose, a lignina, a sílica e os minerais. A solução FDA solubiliza a hemicelulose, ficando no resíduo a celulose, a lignina, a sílica, o nitrogênio e os minerais insolúveis (SILVA e QUEIROZ, 2009).

De acordo com Van Soest (1994), a qualidade dos alimentos volumosos, principalmente as forragens, é influenciada particularmente pela natureza e concentração dos carboidratos estruturais da parede celular. Por essa razão, é importante conhecer as frações que compõem a fibra, pois essa composição influencia diretamente $o$ aproveitamento do alimento por parte do animal, como apresentado anteriormente.

O teor de FDN presente na dieta está relacionado com a limitação do consumo, em razão do espaço ocupado no rúmen, levando-o ao enchimento (OLIVEIRA et al., 2011). Quando ocorre o enchimento do rúmen, a fibra exerce pressão sobre a sua parede, desencadeando respostas fisiológicas que ativam o processo de ruminação e fazendo com que o animal pare de consumir (BERCHIELLI et al., 2006).

Segundo Carvalho e Pires (2008), a proporção dos tecidos e espessura da parede celular têm impacto no valor nutritivo do alimento. Isso acontece pois os teores de fibra, lignina e proteína bruta afetam os coeficientes de digestibilidade in vitro da matéria seca. Assim, os tecidos de baixa digestão (fibra e lignina) afetam negativamente a digestibilidade in vitro da matéria seca do alimento.

Apesar de o teor de fibra limitar o consumo e a digestibilidade dos nutrientes, por se tratar de um componente estrutural da parede celular, em ruminantes a fibra é essencial para estimular a mastigação e a ruminação (WEISS, 1999). O teor de fibra, principalmente do FDN, tem como principal efeito benéfico a manutenção da saúde ruminal, por causa da mastigação e da ruminação, que servem de estímulo para uma maior produção de saliva, que exerce um efeito tamponante sobre o rúmen em razão da alcalinidade que ela apresenta em ruminantes, com um pH em torno de 9,0 (OLIVEIRA et al., 2013).

Outro fator que exerce influência no desempenho e na produção animal é a taxa de degradação da fração fibrosa, principalmente do FDN. Essa degradação é um fator determinante na avaliação da qualidade da dieta. Estudos realizados por Grant et al. (1995) e Dado e Allen (1996) com dietas com teor de FDN e proteína bruta parecidos, porém com diferentes coeficientes de digestibilidade do FDN, mostraram que os animais alimentados com as dietas com maior digestibilidade do FDN obtiveram maior consumo de matéria seca e produção de leite. Oba e Allen (1999), avaliando o desempenho de vacas de leite alimentadas com silagens de 
diferentes espécies forrageiras, observaram que as com maior coeficiente de digestibilidade do FDN apresentaram maior consumo de matéria seca, produção de leite e produção de leite corrigida.

O teor de fibra também influencia as funções metabólicas e fisiológicas dos animais, dependendo da constituição da fração fibrosa, que pode agir na motilidade do trato gastrointestinal e, consequentemente, na excreção, capacidade de hidratação, volume, $\mathrm{pH}$ e fermentabilidade do bolo alimentar e na atividade da população microbiana, ruminal e intestinal (REFSTIE et al., 1999; VAN
SOEST, 1994; ANNISON e CHOCT, 1994; WENK, 2001).

\section{Microrganismos ruminais degradadores de fibra}

\section{- Bactérias}

Os grupos de bactérias que degradam fibras são: celulolíticas, hemicelulolíticas, degradadoras de pectina e xilanas. As espécies pertencentes a esses grupos estão apresentadas na Tabela 1.

Tabela 1. Principais espécies de bactérias degradadoras de fibra.

\begin{tabular}{cc}
\hline \multicolumn{2}{c}{ Espécies bacterianas fermentadoras de carboidratos fibrosos } \\
\hline \multicolumn{1}{c}{ Celulolíticas } & Hemicelulolíticas \\
\hline Ruminococcus albus & Butyrivibrio fibrisolvens \\
Ruminococcus flavefaciens & Prevotella ruminicola \\
Bacterioides succinogenes & Bacterioides ruminicola \\
Butyrivibrio fibrisolveins & Eubacterium xylanophilum \\
Clostridiun lochheadii & E. uniformis \\
Cillobacterium cellulosolvens & \\
Clostridun longisporum & \\
\hline
\end{tabular}

Fonte: adaptado de Oliveira et al. (2007)

As bactérias degradadoras de fibra têm taxa de crescimento mais lenta e são dependentes de amônia e ácidos graxos de cadeia ramificada para sintetizar suas proteínas, são elas: isovalerato, isobutirato e 2metilbutirato (KOZLOSKI, 2002). As espécies bacterianas fermentadoras de CF geram como principais produtos $\mathrm{o}$ acetato, $\mathrm{o}$ propionato, $\mathrm{O}$ butirato, o succinato, o formato, o $\mathrm{CO}_{2}$ e o $\mathrm{H}_{2}$. A degradação se dá pela ação de enzimas extracelulares liberadas pelas bactérias, que destroem os componentes da parede celular (DEHORITY, 1986). Para isso, as bactérias se aderem à fibra liberando suas enzimas. A aderência da célula bacteriana à fibra se dá por meio de interações iônicas, hidrofóbicas e forças de Van Der Walls, tendo também a participação de cátions divalentes, como cálcio e magnésio (KOZLOSKI, 2002). Cerca de 70 a $80 \%$ da biomassa bacteriana ruminal se encontra aderida às partículas, nas quais exercem as atividades de degradação das partículas do alimento.

\section{- $\quad$ Protozoários}

Os protozoários foram detectados nos animais domésticos no século XIX, por Gruby e Delafond (1843). Os protozoários presentes no rúmen são constituídos, em sua maior parte, por ciliados pertencentes a dois grupos, os Entodiniomorfos e os Holotrichas. Os primeiros estão presentes em maior número nas dietas à base de forragem, já o segundo grupo é encontrado em maior quantidade em dietas ricas em concentrados (OLIVEIRA et al., 2007). Os protozoários representam de 40 a $60 \%$ da biomassa microbiana ruminal, por conta de seu tamanho (RUIZ, 1992).

Os protozoários podem ser classificados como utilizadores de açúcar, os que degradam amido e os que hidrolisam celulose (OGIMOTO e IMAI, 1981). Os Entodiniomorfos são capazes de se aderir às fibras e possuem atividade celulolítica e hemicelulolítica (Oliveira et al., 2007). Os protozoários fermentam os açúcares e parte dos aminoácidos, até mesmo o $\mathrm{AGV}$, o $\mathrm{CO}_{2}$ e a amônia. Os protozoários fermentam lactato, diminuindo o efeito depressivo do $\mathrm{pH}$ ruminal em dietas ricas em amido (WILLIANS, 1993).

\section{- $\quad$ Fungos}

Os fungos foram identificados no rúmen pela primeira vez em 1910, mas se 
acreditava que eram protozoários flagelados (KAMRA, 2005). Os fungos presentes no rúmen são quitridiomicetos anaeróbicos, que produzem zoósporos flagelados (ORPIN, 1975). As principais espécies presentes no inóculo ruminal são: Callimastix, Sphaeromonas, Oikomonas, entre outros (OLIVEIRA et al., 2007).

Os fungos presentes no ambiente ruminal são obrigatoriamente anaeróbicos e colonizam as fibras. A colonização ocorre nas regiões lignificadas das fibras, tendo atividade fibrolítica mais intensa (KOZLOSKI, 2002). Os zoósporos móveis dos fungos se aderem aos fragmentos das forragens, penetrando nos tecidos vegetais por meio dos talos e dos rizoides (BAUCHOP, 1989). Os principais produtos gerados pela fermentação dos fungos são o acetato, o lactato, o succinato, o $\mathrm{CO}_{2}$ e o $\mathrm{H}_{2}$.

Duarte et al. (2013), avaliando fungos anaeróbicos do rúmen de bezerras e vacas leiteiras alimentadas com diferentes volumosos tropicais, observaram que houve maior detecção (100\%) nas vacas alimentadas com Brachiaria brizantha, em comparação com as alimentadas com silagem de sorgo $(33,3 \%)$. Os autores informam que as estruturas fúngicas encontradas como múltiplos zoosporângios e rizomicélios bulbosos, sugerem a presença do gênero Caecomyce. Abrão et al. (2010), ao investigar fungos e anaeróbios do rúmen de bovinos e caprinos de corte criados em pastagens tropicais, observaram alta taxa de detecção de fungos monocêntricos $(53,3 \%)$, não havendo diferença entre caprinos e bovinos. Em fungos policêntricos, notou-se uma diferença entre bovinos e caprinos, com médias de observação de 26,1 e 50,0\%, respectivamente.

\section{Degradação de carboidratos fibrosos e a relação com a produção de metano}

A fermentação de carboidratos fibrosos no rúmen favorece o desenvolvimento de microrganismos metanogênicos. Esses microrganismos são pertencentes ao grupo Archaea, metanogênicos dos gêneros Methanobrevibacter, Methanobacterium, Methanomicrobium e Methanosarcina, bem como de fungos e protozoários pertencentes ao domínio Eukarya.

A produção de metano oriunda da fermentação dos $\mathrm{CF}$ ocorre em razão da maior liberação de $\mathrm{H}_{2}$ no ambiente ruminal (JOHNSON e JOHNSON, 1995; NUSSIO et al., 2006), visto que o hidrogênio é o principal substrato utilizado pelas metanogênicas para sintetizar $\mathrm{CH}_{4}-\mathrm{o}$ metano é um subproduto da fermentação ruminal (BERCHIELLE, et al., 2006). Além disso, os carboidratos fibrosos têm maior tempo de permanência no ambiente ruminal, por serem fermentados de forma mais lenta, favorecendo a metanogênese (McALLISTER et al., 1996). Desse modo, a fermentação das gramíneas tropicais ocasiona um aumento na produção de metano, por causa da maior proporção de carboidratos fibrosos em sua estrutura celular (PEDREIRA et al., 2009; BERCHIELLI et al., 2012).

A importância da produção de metano no rúmen se dá pela redução de $\mathrm{H}$ no ambiente ruminal, o que auxilia na regulação do $\mathrm{pH}$ (JOHNSON e JOHNSON, 1995). No entanto, a produção de metano significa perda de energia bruta da dieta, visto que cerca de $12 \%$ da energia é perdida via produção de metano (RUSSELL, 2002). Contudo, a produção de metano em nível ruminal está condicionada à dieta e a características inerentes ao animal dietas com maior proporção de carboidratos de baixa digestão aumentam a metanogênese.

Em estudo realizado por Primavesi et al. (2004) com vacas holandesas mestiças e puras, observou-se que a produção de metano varia de 11,6 a 16,8 g/hora. Já Abdalla et al. (2008), ao avaliar a inclusão de subprodutos da indústria de biodiesel na alimentação de ruminantes, notaram que o farelo de soja apresentou uma produção de metano de 15,3 $\mathrm{mL} / \mathrm{g}$ de matéria orgânica verdadeiramente digerida, enquanto as tortas de algodão, dendê, mamona, pinhão manso I e pinhão manso II produziram 13,$4 ; 11,1 ; 11,8 ; 9,5$ e 13,2 ; respectivamente.

\section{Carboidratos não fibrosos}

Os carboidratos não fibrosos (CNF) são um grupo de biomoléculas compostas por carbono $(\mathrm{C})$, hidrogênio $(\mathrm{H})$ e oxigênio $(\mathrm{O})$, com propriedades funcionais diversas e que estão presentes no conteúdo celular vegetal (ANTUNES et al., 2011). A maioria dos carboidratos contém similares concentrações de energia bruta, sendo variável em energia digestível e energia metabolizável (BRANDI e FURTADO, 2009). Os carboidratos não fibrosos são representados pelas frações degradas mais rapidamente no trato digestório (açúcares, pectina e amido) dos ruminantes.

Os açúcares são mono, di ou oligossacarídeos que possuem como 
característica a solubilidade em água. A glicose é o monossacarídeo mais importante do grupo dos carboidratos não fibrosos, sendo constituinte de compostos energéticos e chave na nutrição e alimentação de ruminantes, como a sacarose da cana-de-açúcar e o amido dos grãos de cereais, tubérculos e raízes. O açúcar mais abundante de interesse nutricional é a sacarose, composta pela ligação covalente da glicose com a frutose. A fonte mais importante desses carboidratos nos países tropicais é a cana-de-açúcar (ANTUNES et al., 2011).

Azevedo et al. (2003) avaliaram a composição, o fracionamento de carboidratos e a degradação in vitro de três variedades de cana-de-açúcar. A melhor variedade apresentou $27,8 \%$ da fração $\mathrm{C}$ (fração não degradável) e 33,3\% da fração B2 (fração potencialmente degradável) dos carboidratos. Encontrou-se, para a mesma variedade, o tempo de colonização e a degradabilidade efetiva da FDN de 7,9 h e $10,3 \%$. Fernandes et al. (2001) estimaram a produção de leite para vacas alimentadas com cana-de-açúcar contendo diferentes teores de FDN (40, 50 e $60 \%$ de FDN) e encontraram taxas de digestão 10,14 e 18\%/h dos carboidratos não fibrosos (CNF), respectivamente. Tal constatação permite inferir que os melhores teores das frações mais facilmente degradáveis dos carboidratos (pectina, amido e açúcares) mantêm um bom desenvolvimento microbiano no rúmen.

Segundo Antunes et al. (2011), os açúcares são fermentados rápida $\mathrm{e}$ completamente no rúmen pelos microrganismos, sendo convertidos em ácidos graxos voláteis e, ocasionalmente, em quantidades significativas de lactato; dessa forma, não é esperado que quantidades significativas de açúcares passem para o intestino delgado e sejam digeridas por ele.

Encontrado em diversos alimentos, o amido é a mais importante fonte de carboidratos não fibrosos da dieta e está amplamente distribuído em diversas espécies vegetais como carboidrato de reserva, sendo abundante em grãos de cereais, raízes e tubérculos (WALTER et al., 2005).

$\mathrm{O}$ amido é sintetizado em estruturas vegetais denominadas plastídeos, cromoplastos das folhas e amiloplastos de órgãos de reserva, com base na polimerização da glicose, resultante da fotossíntese (AUGUSTA et al., 2014).

Segundo Kozloski (2002), o amido é um polissacarídeo de reserva das plantas e é constituído por amilose e amilopectina, sendo a amilose um polímero não ramificado de glicose (ligadas por ligações glicosídicas $\alpha-$ $1,4)$, enquanto a amilopectina é altamente ramificada (incluindo ligações do tipo $\alpha-1,6$ nos pontos de ramificação). Esses polissacarídeos são hidrolisados pelas amilases bacterianas do tipo $\alpha$ e $\beta$ e também por $\alpha$ glicosidases, as $\alpha$ - amilases que hidrolisam ligações no interior da cadeia (endoglicosidades), liberando maltose como produto final. Já as $\beta$-amilases atuam no final da cadeia do polímero (exoglicosidases), liberando glicose, moléculas de amilose e amilopectina.

De todos os polissacarídeos, o amido é o único produzido em pequenos agregados individuais, denominados grânulos. Os grânulos de amido possuem, além da amilose e amilopectina, lipídeos, proteínas e minerais. A amilose e a amilopectina representam de $98 \%$ a $99 \%$ de um grânulo de amido, os grânulos de raízes e tubérculos podem conter de $0,006 \%$ a $0,49 \%$ de nitrogênio e até $1 \%$ de lipídeos (ANTUNES et al., 2011).

A digestão do amido é o passo inicial para que ele seja utilizado como fonte de energia pelos microrganismos ruminais e pelos ruminantes (ANTUNES et al., 2011). Alimentos com alto teor de amido favorecem a formação de ácido propiônico no rúmen e podem induzir os animais a distúrbios metabólicos - como a acidose - mais facilmente do que alimentos que promovem fermentação acética (SANTANA NETO et al., 2014). 


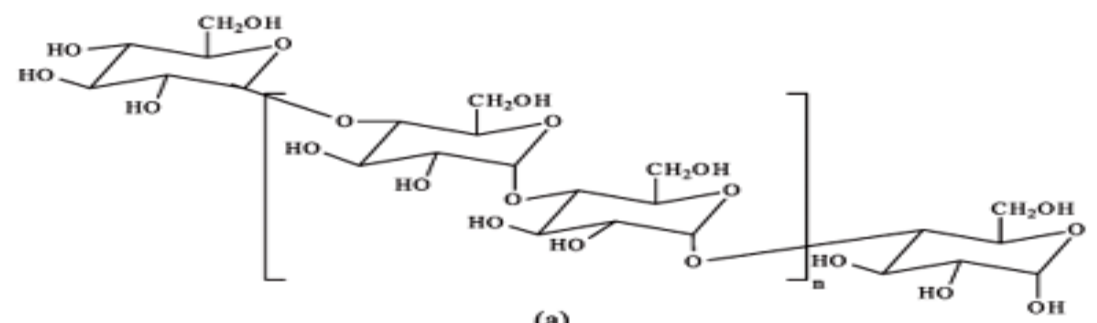

(a)

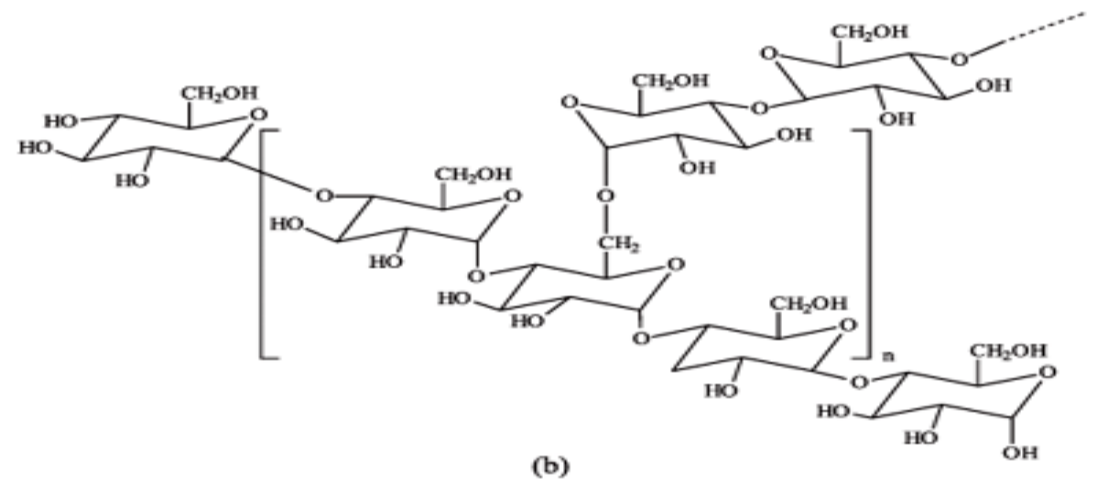

1. Estrutura química da amilose (a) e amilopectina (b). Fonte Corradini et al. (2005)

A pectina é uma substância amorfa parcialmente solúvel em água e completamente solúvel em detergente neutro. Suas moléculas se encontram ligadas covalentemente com a celulose e a hemicelulose (BERCHIELLI et al., 2011). Por apresentar solubilidade em água, a pectina é o composto da parede celular com maior taxa de degradação em nível ruminal. De acordo com Paiva et al., (2009) a pectina está presente em todas as células vegetais e é, junto com a celulose e a hemicelulose, o principal agente cimentante dos vegetais. Segundo Kozloski (2002) a pectina é um heteropolissacarídeo complexo, constituído de cadeias de ácido galacturônico (e seu metil derivado), de galactose e arabinose.

As substâncias pécticas são encontradas primordialmente na lamela média e na parede primária da célula vegetal e podem ser consideradas polímeros lineares compostos de resíduos de ácido 1,4 $\beta$-d-galacturônico esterificado, unidos por ligações glicosídicas do tipo $\alpha 1-4$. Ainda não se conhece o peso molecular exato das pectinas, mas se estima que elas podem conter até 1000 resíduos de monossacarídeos por molécula (WASCHECK et al., 2008).

Os compostos pécticos, que são dissolvidos pela fibra em detergente ácido (FDA), têm relativamente mais condições de formar acetato do que propionato na fermentação ruminal, o que se torna muito desejável (LEIVA et al., 2000). Os subprodutos da agroindústria de frutas, em sua maioria, são ricos em pectina e tem sido largamente utilizados na alimentação de ruminantes, com bons resultados no desempenho produtivo desses animais. Segundo Muller e Prado (2005), a polpa de citrus peletizada é rica em pectina, um carboidrato altamente degradável no rúmen, promovendo um padrão de fermentação ruminal mais adequado, semelhante a dietas à base de volumosos.

Os microrganismos presentes no rúmen são os principais fornecedores de proteína para os ruminantes e o seu desenvolvimento é afetado pela degradação e composição dos carboidratos presentes na dieta (CABRAL, 2000).

\section{Microrganismos degradadores de amido e açúcares}

Os microrganismos são essenciais para o processo de fermentação e digestão dos alimentos fibrosos que os ruminantes consomem. A formação da microbiota no rúmen se dá logo após o nascimento e aumenta até se tornar uma população predominantemente de microrganismos anaeróbios (FURLAN et al., 2011).

Assim, o trato gastrointestinal dos ruminantes é colonizado por uma grande diversidade de microrganismos, sendo que no rúmen estão presentes uma das mais variadas e densas populações microbianas conhecidas na natureza (CZERKAWSKI, 1986). 
O The Cornell Net Carbohydrate and Protein System (CNCPS), sistema criado na universidade de Cornell nos EUA, para classificar os carboidratos e proteínas de acordo com a degradabilidade ruminal desses nutrientes, sugere a divisão do ecossistema ruminal em dois grupos microbianos, ou seja, os microrganismos que utilizam carboidratos fibrosos e os que usam carboidratos não fibrosos (PEREIRA et al., 2005).

A composição dos microrganismos ruminais varia conforme a fase de crescimento microbiano, a disponibilidade de nutrientes e o tipo de microrganismo (OWENS e GOESTCH, 1998 citado por MENDES et al. 2006).

\section{- Bactérias}

Essa população é a mais diversa no rúmen, tanto em termos de número de espécies quanto em capacidade metabólica. A diversidade de bactérias no rúmen é uma das maiores em qualquer ecossistema conhecido (ARCURI et al., 2011).

Algumas espécies de bactérias podem apresentar discrepâncias significativas na sua composição, desde que haja diferença na deita do animal hospedeiro (MENDES et al., 2006). $\mathrm{Na}$ Tabela 2 estão representadas as principais espécies bacterianas degradadoras de carboidratos não fibrosos, estratificadas pelo tipo de substrato que degradam.

Tabela 2. Principais espécies de bactérias fermentadoras de carboidratos não fibrosos.

\begin{tabular}{ccc}
\hline Pectinas & Amido e Maltodextrinas & Açúcares diversos \\
\hline \multicolumn{1}{c}{ Fermentadoras de carboidratos não fibrosos e pectinas } \\
\hline Lachnospira multiparus & Ruminobacter amylophilus & Selenomonas ruminantium \\
& Selenomonas ruminantium & Streptococcus bovis \\
& Prevotella ssp. & Eubacterium ruminantium \\
& Succinomonas amylolytica & \\
& Succinivibrio dextrinosolveins \\
& Streptococcus bovis \\
& Eubacterium ruminantium \\
& Megasphaera elsdenii \\
\hline \multicolumn{3}{c}{ Outros grupos de bactérias* } \\
\hline Butyrivibrio fibrisolvens & Wolinella succinogenes & Butyrivibrio fibrisolvens \\
& Butyrivibrio fibrisolvens & Lacbnospira multiparus \\
& Lactobacilus ssp. & Lactobacilus ssp. \\
& Enterobacter ssp.. & Enterobacter ssp. \\
& Streptococcus ssp. & Streptococcus ssp. \\
\hline
\end{tabular}

*Bactérias preferencialmente fermentadoras de fibra, proteolíticas e facultativas.

Fonte: adaptado de Oliveira et al. (2007).

As bactérias que fermentam carboidratos não fibrosos (CNF) apresentam crescimento mais rápido do que as que fermentam carboidratos fibrosos e utilizam, em média, $66 \%$ de peptídeos e aminoácidos e $34 \%$ de amônia para seu crescimento (RUSSELL et al., 1992). Os grupos de bactérias fermentadoras de CNF geram como principais produtos o acetato, o butirato, o propionato, o lactato, o succinato e o formato. Essas bactérias promovem a maior produção total de ácidos graxos voláteis (AGV), principalmente em razão da maior produção de propionato por meio do ácido láctico (VAN SOEST, 1994).

$\mathrm{O}$ amido é fermentado principalmente por espécies do gênero Bacterióides. Dentre elas, a Bacterióides amilophilus, que utiliza o amido, mas é incapaz de usar a glicose ou outros monossacarídeos (CALDEWLL et al., 1969; MIURA et al., 1980). A Streptococus bovis (MANTOVANI e RUSSELL, 2001) e a Selenomonas rumiantium (FLINT e BISSET 1990 citado por ARCURI et al., 2011) fermentam amido e açúcares solúveis, produzindo acetato - quando esses carboidratos são abundantes -; porém, mudam para acetato, formato e etanol, ou acetato e propionato quando a concentração de substrato prontamente fermentável decresce. Essas últimas rotas metabólicas maximizam a produção de ATP em um ambiente anaeróbico (RUSSELL, 1990).

Os principais microrganismos fermentadores de pectina são o Lachnospira multiparus (DUSKOVA e MAROUNEK, 2001) e o $S$. bovis, além de algumas espécies 
celulolíticas (OSBORNE e DETORITY, 1989).

\section{Protozoários}

Os protozoários do rúmen foram os primeiros microrganismos a serem descritos nesse órgão, provavelmente pelo fato de serem facilmente visualizados quando observados em microscópio óptico (RUIZ, 1992; SIQUEIRA, 2007).

A população de protozoários do conteúdo ruminal de animais alimentados com diferentes tipos de dietas varia em concentração, entre $10^{4}$ a $10^{6}$ protozoários $/ \mathrm{ml}$ de conteúdo ruminal (FRANZOLIN e DEHORITY, 1999; D'AGOSTO et al., 2001).

Do ponto de vista fermentativo, Williams (1986) relatou que alguns protozoários são celulolíticos, mas que os principais substratos utilizados são açúcares e amido, assimilados rapidamente e estocados na forma de amilopectina ou amido protozoário. Portanto, os protozoários desempenham um efeito tamponante, pois as bactérias não têm acesso a uma quantidade excessiva prontamente fermentável, diminuindo assim a concentração de ácido láctico produzido e colaborando para a estabilidade do $\mathrm{pH}$. Consequentemente, a presença de protozoários no rúmen reduz o risco de acidose em dietas ricas em grãos e açúcares (DEHORITY e ORPIN, 1997).

Uma característica peculiar dos protozoários é o quimiotactismo, isto é, a capacidade de se locomover em um gradiente de concentração de açúcares ou glicoproteínas (ARCURI et al., 2011).

\section{Estabelecimento microrganismos no rúmen}

dos

O rúmen é um ecossistema diverso povoado por vários tipos de microrganismos. Para que eles possam se estabelecer, o hospedeiro precisa oferecer condições adequadas, tais como: $\mathrm{pH}$, temperatura, anaerobiose, substrato e taxa de passagem do alimento pelo trato digestório.

O tipo de carboidrato presente na dieta influencia diretamente o desenvolvimento da microbiota ruminal. Isso se deve à especificidade dos microrganismos em degradar determinado tipo de substrato e à alterações no $\mathrm{pH}$ ruminal, que é influenciado pela taxa de fermentação dos carboidratos. Segundo Ørskov e Tyle (1990), o pH ruminal, junto com o substrato disponível para fermentação, são os principais fatores que possibilitam a prevalência dos microrganismos no rúmen.

A influência dos carboidratos fibrosos no $\mathrm{pH}$ ruminal provém da maior produção de saliva (BERCHIELLI et al. 2006), que em ruminantes tem alto poder tamponante $(\mathrm{pH}$ 8,1) (OLIVEIRA et al., 2013). De acordo com Valadares Filho e Pina (2011), dietas com menos de $40 \%$ de forragem reduzem o desenvolvimento da microbiota ruminal, por causa da menor salivação.

De acordo com Hoover (1986), valores de $\mathrm{pH}$ ruminal abaixo de 6,2 reduzem acentuadamente a atividade de degradação da fibra, sendo que em pHs entre 4,5 e 5,0 cessam completamente a atividade fibrolítica no rúmen.

Russell et al. (1979) relataram que a população de bactérias celulolíticas diminuiu quando o pH estava entre 5,7 a 6,2. Já as bactérias fermentadoras de carboidratos solúveis persistiram até em variações de 4,6 a 4,9 .

Quando o $\mathrm{pH}$ do fluido ruminal declina de 6,7 para 6,0, a taxa de utilização dos carboidratos é diminuída (STROBEL e RUSSELL, 1986). Os autores relataram que mesmo pequenos declínios do $\mathrm{pH}$, típicos de eventos ruminais de vacas leiteiras, poderiam ser prejudiciais à síntese de proteína microbiana, pois encontraram redução de $69 \%$ na síntese quando o $\mathrm{pH}$ era igual a 6,0.

Segundo Antunes et al. (2011), o aumento da disponibilidade de carboidratos não fibrosos e a consequente queda de $\mathrm{pH}$ provocam intensas modificações do ecossistema ruminal. A ingestão excessiva de alimentos ricos em carboidratos de fácil fermentação produz grande quantidade de ácido láctico, o qual pode desencadear um quadro de acidose ruminal em razão do abaixamento excessivo do $\mathrm{pH}$ (MARUTA e ORTOLANE, 2002). O pH ruminal está diretamente relacionado aos produtos finais da fermentação e também com a taxa de crescimento dos microrganismos ruminais (ITAVO et al., 2002).

Ørskov (1986) afirmou que o abaixamento do $\mathrm{pH}$ ruminal ocorre, principalmente, após a ingestão de alimentos especialmente concentrados, por causa da sua rápida taxa de fermentação. Portanto, a escolha da fonte de CNF na dieta pode maximizar a síntese de proteína microbiana e manter a saúde ruminal. 


\section{Fatores que afetam a síntese de proteína microbiana}

A síntese de proteína microbiana tem despertado o interesse de pesquisadores nos últimos anos, por influenciar diretamente o desempenho animal (FERREIRA et al.,2009), visto que essa é uma das principais fontes proteicas para os ruminantes, suprindo suas demandas por aminoácidos (NRC, 2001). A elevada produção microbiana diminui a necessidade de suplementação com proteína dietética não degradada no rúmen (DIAS et al., 2008).

Tabela 3. Composição de aminoácidos essenciais dos microrganismos ruminais.

\begin{tabular}{ccccccccccc}
\hline $\begin{array}{c}\text { Microrganismos } \\
\text { ruminais }\end{array}$ & Arg & His & Ile & Leu & Lis & Met & Fen & Ter & Tri & Val \\
\hline Bactéria $^{1}$ & 10,2 & 4,0 & 11,5 & 16,3 & 15,8 & 5,2 & 10,2 & 11,7 & 2,7 & 12,5 \\
Bactéria $^{2}$ & 10,6 & 4,3 & 11,6 & 15,5 & 17,3 & 4,9 & 10,0 & 11,0 & 2,6 & 12,2 \\
Protozoários $^{2}$ & 9,3 & 3,6 & 12,7 & 15,8 & 20,6 & 4,2 & 10,7 & 10,5 & 2,8 & 9,7 \\
\hline
\end{tabular}

Adaptado do NRC (2001). ${ }^{1}$ Valores relatados por Clark et al. (1992), valor obtido de 61 tratamentos de diferentes dietas.

${ }^{2}$ Valores relatados por Storm e Orskov (1983), avaliação de 62 trabalhos publicados.

A dieta é fundamental para otimizar a produção microbiana e sua eficiência fermentativa no ambiente ruminal (MENDES et al., 2006). Para que a proteína microbiana seja sintetizada é necessário haver sincronia entre o fornecimento de energia e nitrogênio: se houver desbalanceamento nessa relação, a síntese de proteína microbiana será afetada.

Segundo Fegradolli et al. (2001), quando a utilização do carboidrato é insuficiente para a síntese de proteína microbiana, há redução na digestão e o nitrogênio é perdido na forma de amônia. De acordo com Silveira et al. (2006), gramíneas de clima temperado promovem um aumento na síntese de proteína microbiana, em razão da alta digestibilidade e do elevado teor de $\mathrm{N}$ degradável. Gramíneas tropicais limitam o desenvolvimento da microbiota ruminal, por possuírem menor digestibilidade e baixo teor proteico, principalmente durante a época seca do ano (MISSON, 1990; KABEYA et al., 2002).

A eficiência de síntese de proteína microbiana tem sido expressa de diferentes formas: em função do NDT (NRC, 1985); em relação à matéria orgânica degradada no rúmen (MODR) (ARC, 1984); em função da energia metabolizável fermentada no rúmen (AFRC, 1993) e em gramas de matéria seca bacteriana (gMSbac), por grama de carboidratos totais degradados no rúmen (CHODR) (CNCPS, descrito por RUSSELL et al., 1992).

Zeoula et al. (2002), ao avaliar a concentração de $\mathrm{N}_{-} \mathrm{NH}_{3}$, verificou $0 \quad \mathrm{pH}$ ruminal e a eficiência de síntese microbiana de rações que continham milho e resíduos do beneficiamento da mandioca como fontes energéticas. Os pesquisadores não encontraram uma diferença significativa entre as dietas para as variáveis $\mathrm{pH}$ ruminal e fluxo duodenal das bactérias ruminais. No entanto, uma menor concentração de $\mathrm{N}-\mathrm{NH}_{3}$ foi observada para a ração contendo farinha de varredura $(\mathrm{FV})$, que apresentou uma concentração de $30,1 \mathrm{~g} \mathrm{~N}$ $\mathrm{Mic} / \mathrm{kg}$ MO aparentemente degradável no rúmen. Assim, é possível inferir que a maior eficiência microbiana aparente foi obtida para a ração com FV.

Segundo Clark et al. (1992), 59\% da proteína que chega ao intestino delgado é de origem microbiana. Todavia, o NRC (1996) sugere que a proteína microbiana pode suprir até $100 \%$ da exigência de proteína metabolizável para bovinos de corte.

A disponibilidade de energia e nitrogênio para os microrganismos é determinada pelas taxas de digestão e passagem pelo rúmen, que influenciam a eficiência e a quantidade de proteína sintetizada (MENDES et al., 2006).

A taxa de passagem consiste no fluxo de resíduos não digeridos pelo trato digestivo. O fluxo ruminal inclui a fibra indigestível, bactérias e outras frações não degradáveis do alimento (MENDES et al., 2006). A origem e o processamento do alimento são variáveis que influenciam a digestão, a taxa de digestão e a reciclagem do conteúdo ruminal (VAN SOEST et al., 1994).

A fermentação ruminal e a passagem de proteína microbiana ou de alimentos para o intestino delgado são afetados pela quantidade de energia e proteína ingerida por meio da dieta (CLARK et al., 1992). As taxas de degradação e de passagem têm um efeito profundo sobre os produtos finais de 
fermentação e sobre o desempenho animal (PEREIRA et al., 2005).

Russell et al. (1992) relatou que: 1) se a taxa de degradação da proteína exceder a taxa de degradação de carboidratos, grandes quantidades de nitrogênio podem ser perdidas na forma de anomia; 2) se a taxa de degradação dos carboidratos for menor do que a das proteínas, ocorre uma redução no crescimento microbiano; 3) se os alimentos são degradados lentamente no rúmen, ocorre um aumento do efeito de repleção ruminal; 4) se a taxa de degradação for lenta, pode haver um maior escape de nutrientes para o intestino delgado.

Os processos de digestão e fermentação executados pelos microrganismos ruminais fornecem como produtos finais da fermentação os AGVs, que são utilizados como fonte de energia para o animal, uma vez que a massa microbiana representa uma fonte de aminoácidos de excelente qualidade para o hospedeiro (PEREIRA et al., 2005). Dessa forma, a eficiência de síntese de proteína microbiana é importante para os requerimentos de proteína metabolizável (MENDES et al., 2006).

Ferreira et al. (2009), ao investigar a síntese de proteína microbiana em vacas alimentadas com palma e diferentes fontes de volumosos (bagaço de cana, feno de Tifton, feno de capim elefante, silagem de sorgo e silagem de sorgo + bagaço de cana), não encontraram diferença na síntese de proteína microbiana e de nitrogênio microbiano entre as fontes de volumosos. Para Casper et al. (1999), alterações na fonte e na degradabilidade de carboidratos não fibrosos na dieta podem aumentar a síntese de proteína microbiana no rúmen e melhorar a eficiência de utilização da proteína não degradável no rúmen. Renó et al. (2000) avaliou a excreção de compostos de N microbiano em dietas com diferentes níveis de concentrado e encontraram comportamento quadrático, com um valor máximo de 93,50 e $106,55 \mathrm{mmol} /$ dia para os níveis com 50,48; 51,42 ; e $53,57 \%$ de concentrado na dieta, respectivamente.

\section{CONSIDERAÇÕES FINAIS}

O tipo e a origem dos carboidratos presentes na dieta influenciam diretamente as condições do ambiente ruminal, em razão, principalmente, de alterações no $\mathrm{pH}$ e no fluxo ruminal, que modificam a população microbiana.
Os carboidratos fibrosos auxiliam na manutenção das condições de pH ruminal, por estimularem a ruminação e uma maior produção de saliva. No entanto, os carboidratos reduzem a síntese de proteína microbiana, por possuírem menor digestibilidade e taxa de fermentação, o que pode refletir no desempenho dos animais.

A presença de carboidratos não fibrosos na dieta leva ao desequilíbrio no $\mathrm{pH}$, porque possuem alta fermentação. Entretanto, por possuírem maior aporte energético, eles levam a um maior desenvolvimento da população microbiana e podem contribuir para um maior desempenho produtivo.

Por essas razões, o sincronismo na relação entre o carboidrato fibroso e o não fibroso e destes com a fonte de nitrogênio disponível na dieta dos ruminantes é de grande importância para manter as condições de ambiente ruminal adequadas e proporcionar eficiência no desenvolvimento dos microrganismos ruminais e dos ruminantes.

\section{FIBROUS CARBOHYDRATE CONCENTRATION AND NON-FIBROUS RUMINANTS IN DIET AND ITS EFFECTS ON MICROBIOTA RUMINAL}

\section{ABSTRACT}

The objective of this review is to evaluate the concentration of fibrous carbohydrates and no fibrous in the diet of ruminants and the effects on ruminal microflora. Carbohydrates are the most abundant biomolecules nature, have structural and energetic function, the main energy source for ruminants. Can be classified according to their structure, function and nutritional point of view, the break of fibrous and non-fibrous carbohydrates. Carbohydrates are fermented in the rumen by action of microbial flora, which has its development directly affected by the type of carbohydrate, for the rumen microorganisms have specificity as to substrate fermenting. In addition to that, the rate of fermentation of carbohydrates in the rumen alters the rumen conditions, directly affecting the development of microorganisms present in it. The non-fibrous carbohydrates have a high rate of fermentation, leading to lowering of ruminal $\mathrm{pH}$, influencing the development of the rumen flora, since the nonfibrous carbohydrates have low fermentation rate, and stimulate rumination and increased salivation animal, which aids in tamponade the $\mathrm{pH}$ of the rumen. Therefore, the balance in the 
supply of fibrous and non fibrous carbohydrate is important for maintaining stable rumen. The main product of ruminal fermentation of carbohydrates are the AGV's, which are used by ruminants as the main energy source.

Keywords: VGA's, microbial flora, rumen

\section{REFERÊNCIAS}

Abdalla, A. L.; Silva Filho, J. C. S.; Godoi, A. R.; Carmo, C. A.; Eduardo, J. L. P. Utilização de subprodutos da indústria de biodiesel na alimentação de ruminantes. Revista Brasileira de Zootecnia, v. 37, suplemento especial, p. 258-260, 2008.

Abrão, F. O.; Barreto, S. M. P.; Geraseev, L. C.; Duarte, E. R. Fungos anaeróbios do rúmen de bovinos e caprinos de corte criados em pastagens tropicais. Revista Brasileira de Medicina Veterinária e Zootecnia, v. 62, n. 3, p. 757-760, 2010.

http://dx.doi.org/10.1590/S0102-

09352010000300036

Alves, P. L.; Magalhães, A. C. N.; Barja, P. R. The phenomenon of photoinhibition of photosynthesis and its importance in reforestation. The Bontanical Review, v. 68, n. 2, p. 193-208, 2002.

http://dx.doi.org/10.1663/0006-

8101(2002)068[0193:TPOPOP]2.0.CO;2

Alves, T. C.; Franzolin, R.; Rodrigues, P. H. M.; Alves, A. C. Efeitos de dietas com níveis crescentes de milho no metabolismo ruminal de energia e proteína em bubalinos. Revista Brasileira de Zootecnia, v. 38, n.10, p. 20012006, 2009.

http://dx.doi.org/10.1590/S1516-

35982009001000021

Annison, E. F.; Lewis, D. Metabolism in the rumen. John Wiley \& Sons Inc. 184 p. 1862.

ANTUNES, R. C.; RODRIGUEZ, N. M.; SALIBA, E. O. S. Metabolismo dos carboidratos não estruturais. IN: Nutrição de ruminantes. Jaboticabal: Funep, 2011.

ARCURI, P. B.; LOPES, F. C. F.; CARNEIRO, J. C. Microbiologia do rúmen. IN: BERCHIELLI, T.T. et al. Nutrição de Ruminantes. Jaboticabal: Funep, 2011.
Augusta, G.; Costa, J.P.; Pires, M. A. G.; Filgueiras, M. L. M.; Oliveira, L. F.; Oliveira, I. T. Bolinho de mandioca saborizado com presunto e mussarela. Revista Faculdade Montes Belos, v. 7, n. 1, p. 26-40, 2014.

Azevêdo, J. A. G.; Pereira, J. C.; Queiroz, A. C.; Carneiro, P. C. S.; Lana, R. P.; Barbosa, M. H. P.; Fernandes, A. M.; Rennó, F. P. Composição Químico-Bromatológica, Fracionamento de Carboidratos e Cinética da Degradação in vitro da Fibra de Três Variedades de Cana-de-Açúcar (Saccharum spp.). Revista Brasileira de Zootecnia, v. 32, n. 6, p. 1443-1453, 2003.

http://dx.doi.org/10.1590/S151635982003000600019

BAUCHOP, T. Colonization of plant fragments by protozoa and fungi. (Eds). The roles of protozoa and fungi in ruminant digestion. Armidale: Penambul Books, p. 8396, 1989.

Berchielli, T. T.; Messana, J. D.; Canesin, R. C. Produção de metano entérico em pastagens tropicais. Revista de Saúde e Produção Animal, v. 13, n. 4, p. 954-968, 2012.

http://dx.doi.org/10.1590/S1519-

99402012000400010

Berchielli, T. T.; Pires, A. V.; Oliveira, S. G. Nutrição de ruminantes. Jaboticabal: Funep, p. 616, 2006.

Brandi, R. A.; Furtado, C. E. Correspondências devem ser enviadas para: Importância nutricional e metabólica da fibra na dieta de equinos. Revista Brasileira de Zootecnia, v. 38, p. 246-258, 2009.

http://dx.doi.org/10.1590/S151635982009001300025

Cabral, L. S.; Valadares Filho, S. C.; Detmann, E.; Zervoudakis, J. T.; Pereira, O. G.; Veloso, R. G.; Pereira, E. S. Cinética ruminal das frações de carboidratos, produção de gás, digestibilidade In Vitro da matéria seca e NDT estimado da silagem de milho com diferentes proporções de grãos. Revista Brasileira de Zootecnia, v. 31, n. 6, p. 2332-2339, 2002. http://dx.doi.org/10.1590/S151635982002000900023

Cabral, L. S.; Valadares Filho, S. C.; Malafaia, P. A. M.; Lana, R. P.; Silva, J. F. C.; Vieira, R. 
A. M.; Pereira, E. S. Frações de Carboidratos de Alimentos Volumosos e suas Taxas de Degradação Estimadas pela Técnica de Produção de Gases. Revista Brasileira de Zootecnia, v. 29, n. 6, p. 2087-2098, 2000.

Caldwell, D. R.; Keeney, M.; Van Soest, P. J. Effects of Carbon Dioxide on Growth and Maltose Fermentation by Bacteroides amylophilus. Journal Bacteriology, v. 98, n. 2, p. $668,1969$.

Cameron, M. R., Klusmeyer, T. H., Lynch, G. L.; Clark, J. H.; Nelson, D. R. Effects of urea and starch on rumen fermentation nutrient passage to the duodenum and performance of cows. Journal Dairy Science, 74 (4):13211336., 1991.

http://dx.doi.org/10.3168/jds.S0022-

0302(91)78288-X

Campos, F. P.; Lanna, D. P. D.; Bose, M. L. V.; Boin, C.; Sarmento, P. Degradabilidade do capim-elefante em diferentes estágios de maturidade avaliada pelo método in vitro de produção de gás. Scientia Agricola, v. 59, n. 2, p. 217-225, 2002.

http://dx.doi.org/10.1590/S0103-

90162002000200003

Carvalho, G. G. P.; Pires, A. J. V. Organização dos tecidos de plantas forrageiras e suas implicações para os ruminantes. Archivos de Zootecnia, v. 57, p. 13-28, 2008.

Casper, D. P.; Maiga, H. A.; Brouk, M. J.; Schingoethe, D. J. Synchronization of carbohydrate and protein sources on fermentation and passage rates in dairy cows. Journal Dairy Science, v. 82, p. 1779-1790, 1999.

http://dx.doi.org/10.3168/jds.S0022-

0302(99)75408-1

Church, D. C. The ruminant animal: digestive physiology and nutrition. Englewood Cliffs: Waveland Press, p. 563, 1988.

Clark, J. H.; Klusmeyer, T. H. E.; Cameron, M. R. Microbial protein synthesis and flows of nitrogen fractions to the duodenum of dairy cows. Journal Dairy Science, v. 75, n. 8, p. 2304-2323, 1992.

http://dx.doi.org/10.3168/jds.S0022-

0302(92)77992-2
Corradini, E.; Lotti, C.; Medeiros, E. S.; Carvalho, A. J. F.; Curvelo, A. A. S.; Mattoso, L. H. C. Estudo Comparativo de Amidos Termoplásticos Derivados do Milho com Diferentes Teores de Amilose. Polímeros: Ciência e Tecnologia, v. 15, n. 4, p. 268-273, 2005.

Dado, R. G.; Allen, M. S. Enhanced intake and production of dairy cows offered ensiled alfafa with higher neutral detergent fiber digestibility. Journal of Dairy Science, n. 3, v. 79, p. 418428, 1996.

http://dx.doi.org/10.3168/jds.S00220302(96)76381-6

DEHORITY, B. A. Protozoa of the digestive tract of herbivorous mammals. Insect Science Applied, v. 7, p. 279-296. 1986.

http://dx.doi.org/10.1017/s1742758400009346

Dehority, B. A.; Orpin, C. G. Development of, and natural fluctuations in, rumen microbial populations. In: Hobson, P. N.; Stewart, C. S. (Ed.). The rumen microbial ecosystem. London: Blackie Academic, v. 2. p. 196-245, 1997.

http://dx.doi.org/10.1007/978-94-009-14537 5

Detmann, E.; Paulino, M. F.; Valadares Filho, S. C.; Cecon, P. R.; Zervoudakis, J. T.; Cabral, L. S.; Gonçalves, L. C.; Valadares, R. F. D. Níveis de proteína em suplementos para terminação de bovinos em pastejo durante período de transição seca/águas: digestibilidade aparente e parâmetros do metabolismo ruminal e compostos nitrogenados. Revista Brasileira de Zootecnia, v. 34, p. 1380-1391, 2005.

http://dx.doi.org/10.1590/S1516-

35982005000400036

Dias, M.; Leão, M. I.; Detmann, E.; Valadares Filho, S. C.; Vasconcelos, A. M.; Souza, S. M.; Paulino, M. F.; Murça, T. B. Técnicas para estimativa da digestibilidade e produção microbiana em bovinos. Revista Brasileira de Zootecnia, v. 37, n. 3, p. 504-512, 2008. http://dx.doi.org/10.1590/S151635982008000300016

Duarte, E. R.; Almeida, P. N. M.; Freitas, C. E. S.; Abrão, F. O.; Ribeiro, I. C. O.; Vieira, E. A. Fungos anaeróbios do rúmen de bezerras e vacas leiteiras alimentadas com diferentes 
volumosos tropicais. Revista Brasileira de Medicina Veterinária, 35(3):260-266, 2013.

Dusïkova, D.; Marounek, M. Fermentation of pectin and glucose, and activity of pectindegrading enzymes in the rumen bacterium Lachnospira multiparus. Letters in Applied Microbiology, v. 33, p. 159-163, 2001.

http://dx.doi.org/10.1046/j.1472-

765x.2001.00970.x

Fernandes, A. M.; Queiroz, A. C.; Lana, R. P.; Pereira, J. C.; Cabral, L. S.; Vittori, A.; Pereira, E. S. Estimativas da Produção de Leite por Vacas Holandesas Mestiças, Segundo o Sistema CNCPS, em Dietas Contendo Canade-Açúcar com Diferentes Valores Nutritivos. Revista Brasileira de Zootecnia, v. 30, n. 4, p. 1350-1357, 2001.

http://dx.doi.org/10.1590/S1516-

35982001000500031

Ferreira, M. A.; Silva, R. R.; Ramos, A. O.; Véras, A. S. C.; Melo, A. A. S.; Guimarães, A. V. Síntese de proteína microbiana e concentrações de ureia em vacas alimentadas com dietas à base de palma forrageira e diferentes volumosos. Revista Brasileira de Zootecnia, v. 38, n. 1, p. 159-165, 2009.

http://dx.doi.org/10.1590/S1516-

35982009000100020

FURLAN, R. L.; MACARI, M.; FARIA FILHO, D. E. Anatomia e Fisiologia do Trato Gastrintestinal. IN: BERCHIELLI, T. T. et al. Nutrição de Ruminantes. Jaboticabal: Funep, 2011.

Grant, R. J.; Haddad, S. G.; Moore, K. J. et al. Brown midrib sorghum silage for midlactation dairy cows. Journal of Dairy Science, n. 9, v. 78, p. 1970-1980, 1995.

http://dx.doi.org/10.3168/jds.S0022-

0302(95)76823-0

Gruby, D.; Delafond, H. M. O. Recherches sur des animalcules se développant en grand nombre dans l'estomac et dans les intestins, pendant la digestion des animaux herbivores et carnivores. Competes Rendus Hebdomadaires Seánces Academic Science, v. 17, p. 13041308, 1843.

Hall, M. B. Selection of an empirical detection method for determination of water-soluble carbohydrates in feedstuffs for application in ruminant nutrition. Animal Feed Science and Technology, v. 198, p. 28-37, 2014.

http://dx.doi.org/10.1016/j.anifeedsci.2014.08. 009

Hoover, W. H. Chemical factors involved in ruminal fiber digestion. Journal Dairy Science, v. 69, p. $2755-2766,1986$.

http://dx.doi.org/10.3168/jds.S0022-

0302(86)80724-X

Ítavo, L. C. V.; Valadares Filho, S. C.; Silva, F. F.; Valadares, R. F. D.; Leão, M. I.; Cecon, P. R.; Ítavo, C. C. B. F.; Moraes, E. H. B. K.; Rennó, L. N.; Paulino, P. V. R. Produção Microbiana e Parâmetros Ruminais de Novilhos Alimentados com Dietas Contendo Vários Níveis de Concentrado. Revista Brasileira de Zootecnia, v. 31, n. 3, p. 15531561, 2002.

http://dx.doi.org/10.1590/S1516-

35982002000600027

JAYANI, R. S.; SAXENA, S.; GUPTA, S. R. Microbial pectinolytic enzymes: A review. Process Biochemical, v. 40, 2931, 2005. http://dx.doi.org/10.1016/j.procbio.2005.03.02 6

Johnson, K. A.; Johnson, D. E. Methane emissions from cattle. Journal Animal Science, v. 73, n. 8, p. 2483-2492, 1995.

http://dx.doi.org/10.2527/1995.7382483x

Kabeya, K. S.; Paulino, M. F.; Detmann, E.; Valadares Filho, S. C.; Cecon, P. R.; Queiroz, D. S.; Gomes Júnior, P.; Pereira, O. G. Suplementação de novilhos mestiços em pastejo na época de transição água-seca: desempenho produtivo, características físicas de carcaça, consumo e parâmetros ruminais. Revista Brasileira de Zootecnia, v. 31, n. 1, p. 213-222, 2002.

http://dx.doi.org/10.1590/S151635982002000100024

Kamra, D. N.; Pathak, N. N. Nutritional Microbiology of Farm Animals. Vikas Publishing House, p. 1-224, 1996.

Kosloski, G. V. Bioquímica dos ruminantes. $2^{\mathrm{a}}$ edição, revista ampliada, editora UFSM. Santa Maria, 2002.

Kovács, P. L.; Südekun, K. H.; Stangassinger, M. Effects of intake of mixed diets and time 
post feeding on amount and fiber composition of ruminal and fecal particles and on digesta passage from the reticulo-rumen of steers. Animal Feed Science and Technology, v. 71, n. 3-4, p. 325-340, 1998.

http://dx.doi.org/10.1016/S0377-

8401(97)00141-7

Leiva, E.; Hall, M. B.; Van Horn, H. H. Performance of Dairy Cattle Fed Citrus Pulp or Corn Products as Sources of Neutral Detergent-Soluble Carbohydrates. Journal Dairy Science, n. 83, p. 2866-2875, 2000.

http://dx.doi.org/10.3168/jds.S0022-

0302(00)75187-3

Macedo Júnior, G. L.; Zanine, A. M.; Borges, I.; Pérez, J. R. O. Qualidade da fibra para a dieta de ruminantes. Ciência Animal, 17(1):717, 2007.

Manella, M. Q.; Lourenço, A. J.; Leme, P. R. Recria de bovinos Nelore em pastos de Brachiaria brizantha com suplementação proteica ou com acesso a banco de proteína de Leucaena lecocephala. Característica de fermentação ruminal. Revista Brasileira de Zootecnia, v. 32, n. 4, p. 1002-1012, 2003.

http://dx.doi.org/10.1590/S1516-

35982003000400028

Mantovani, H. C.; Russell J. B. Nisin Resistance of Streptococcus bovis. Applied and Environmental Microbiology, v. 67, n. 2, p. 808, 2001.

http://dx.doi.org/10.1128/AEM.67.2.808813.2001

Maruta, C. A.; Ortolani, E. L. Susceptibilidade de Bovinos das Raças Jersey e Gir à Acidose Láctica Ruminal: Ii - Acidose Metabólica e Metabolização do Lactato-L. Ciência Rural, v. 32, n. 1, p. 61-65, 2002.

http://dx.doi.org/10.1590/S0103-

84782002000100011

McAllister, T. A.; Okine, E. K.; Mathison, G. W.; Cheng, K. J. Dietary, environmental and microbiological aspects of methane production in ruminants. Canada Journal Animal Science, v. 76, p. 231-243, 1996

http://dx.doi.org/10.4141/cjas96-035

Mendes, A. R.; Ezequiel, J. M. B.; Galati, R. L.; Nascimento, V. F.; Queiroz, M. A. A.; Pereira, E. M. O. Cinética digestiva e eficiência de síntese de proteína microbiana em novilhos alimentados com farelo de girassol e diferentes fontes energéticas. Revista Brasleira de Zootecnia, v. 35, n. 1, p. 264-274, 2006.

http://dx.doi.org/10.1590/S151635982006000100034

MERTENS, D. R. Creating a system for meeting the fiber requirement of dairy cows. et, v. 80, p. 1463, 1997.

Minson, D. J. Forage in ruminant nutrition. Academic Press, p. 483, 1990.

Miura, H.; Horiguchi, M.; Matsumoto, T. Nutritional Interdependence Among Rumen Bacteria, Bacteroides amylophilus, Megasphaera elsdenii, and Ruminococcus albus. Applied and Environmental Microbiology, v. 40, n. 2, p. 294, 1980.

Müller, M.; Prado, I. N. Metabolismo da Pectina em Animais Ruminantes - Uma Revisão. Revista Varia Scientia, v. 04, n. 08, p. 45-56, 2004.

NATIONAL RESEARCH COUNCIL. Nutrient Requirements of Beef Cattle. Washington, D. C. National Academy Press. 1996.

NATIONAL RESEARCH COUNCIL. Nutrient Requirements of Dairy Cattle. $7^{\mathrm{a}}$ ed. Washington: National Academy Press, p.340, 2001.

NUSSIO, L. G.; CAMPOS, F. P.; LIMA, M. L. M. Metabolismos de carboidratos estruturais. IN: Nutrição de ruminantes. $2^{\circ} \mathrm{Ed}$. Jaboticabal: SP, cap. 07, p. 183- 223, 2006.

Oba, M.; Allen, M. S. Evaluation of the importance of the digestibility of neutral detergent fiber from forage: effects on dry matter intake and milk yield of dairy cows. Journal of Dairy Science, n. 3, v. 82, p. 589596, 1999.

http://dx.doi.org/10.3168/jds.S0022-

0302(99)75271-9

Ogimoto, K.; Imai, S. Atlas of rumen microbiology. Japan Science Society, Press, p. $231,1981$.

OLIVEIRA, V. S.; SANTANA NETO, J. A.; VALENÇA, R.L. Características químicas e fisiológicas da fermentação ruminal de bovinos em pastejo - revisão de literatura. Revista 
Cientifica Eletrônica de Medicina Veterinária, ano XI, n. 20, 2013.

Oliveira, V. S.; Fagundes, J. L.; Santana Neto, J. A.; Valença, R. L.; Santos, A. C. P.; Rangel, J. H. A. Comportamento Ingestivo Diurno de Bovinos em Sistema Silvipastoril na Região do Sertão Sergipano. Revista Científica de Produção Animal, v. 13, n. 1, p. 1-6, 2011. http://dx.doi.org/10.15528/2176-

4158/rcpa.v13n1p1-6

Oliveira, J. S.; Zanine, A. M.; Santos, E. M. Processo fermentativo, digestivo e fatores antinutricionais de nutrientes para ruminantes. REDEVET, v. 8, n. 2, p. 1-13, 2007.

OLIVEIRA, J. S.; ZANINE, A. M.; SANTOS, E. M. Diversidade microbiana no ecossistema ruminal. v. 8, n. 6, p. 1-12, 2007.

Orpin, C. G. Studies on the rumen flagellate Neocallimastix frontalis. Journal of General Microbiology, 91:249, 1975. http://dx.doi.org/10.1099/00221287-91-2-249

$\emptyset$ RSKOV, E. R. Starch digestion and utilization in ruminants. Journal Animal Science, v. 63, n. 5, p. 1624-1633, 1986. http://dx.doi.org/10.2527/jas1986.6351624x

Ørskov, E. R.; Tyle, M. Energy nutrition in ruminants. Cambridge: Elsevier Science Publishers. p. 146, 1990.

Paiva, E. P.; Lima, M. S.; Paixão, J. A. Pectina: propriedades químicas e importância a estrutura da parede celular de frutos durante o processo de maturação. Revista Iberoamericana de Polimero, v. 10, 2009.

Pedreira, M. S.; Primavesi, O.; Lima, M. A.; Frighetto, R. T.;.OLIVEIRA, S. G.; BERCHIELLI, T. T. Ruminal methane emission by dairy cattle in southeast Brazil. Scientia Agricola, v. 66, p. 742-750, 2009.

http://dx.doi.org/10.1590/S0103-

90162009000600004

Pereira, E. S.; Arruda, A. M. V.; Miranda, L. F.; Mizubuti, I. Y.; Muniz, E. B.; Pinto, A. P. Importância da inter-relação carboidrato e proteína em dietas de ruminantes. Semina: Ciências Agrárias, v. 26, n. 1, p. 125-134, 2005. http://dx.doi.org/10.5433/1679-

$0359.2005 \mathrm{v} 26 \mathrm{n} 1 \mathrm{p} 125$

Russell, J. B.; Sharp, W. M.; Baldwin, R. L. The effect of $\mathrm{pH}$ on maximum bacterial growth rate and its possible role as a determinant of bacterial competition in the rumen. Journal Animal Science, v. 48 p. 251, 1979.

http://dx.doi.org/10.2527/jas1979.482251x

Russell, J. B. Low-affinity, high-capacity system of glucose transport in the ruminal bacterium Streptococcus bovis: evidence for a mechanism of facilitated diffusion. Applied and Environmental Microbiology, v. 56, n. 11, p. 3304, 1990.

Russell, J. B.; O'Connor, J. D.; Fox, D. G.; Van Soest, P. J.; Sniffen, C. J. A net carbohydrate and protein system for evaluating cattle diets: I. Ruminal fermentation. Journal Animal Science, v. 70, p. 3551-3561, 1992. http://dx.doi.org/10.2527/1992.70113551x

Russell, J. B. Rumen microbiology and its role in ruminant nutrition. Ithaca, NY: Cornell University Press, p. 121, 2002.

SANTANA NETO, J. A.; OLIVEIRA, V. S.; VALENÇA, R. L. Características da fermentação ruminal de ovinos em pastejo revisão de literatura. Revista Científica Eletrônica de Medicina Veterinária, ano X, n. 19, 2012.

Santana Neto, J. A.; Oliveira, V. S.; Santos, A. C. P.; Valença, R. L. Distúrbios metabólicos em ruminantes - Uma revisão. Revista Brasileira de Higiene e Sanidade Animal, v. 8, n. 4, p. 157-186, 2014.

Silva, J. F. C.; Leão, M. I. Fundamentos da Nutrição de Ruminantes. Piracicaba. p. 384, 1979.

Silva, D. J.; Queiroz, A. C. Análise de alimentos (métodos químicos e biológicos). Viçosa, MG: Universidade Federal de Viçosa, p. 235, 2009.

Silveira, M. F.; Kozloski, G. V.; Brondani, I. L.; Alves Filho, D. C.; Restle, J.; Leite, D. T.; Metz, P. A. M.; Silveira, S. R. L. Ganho de peso vivo e fermentação ruminal em novilhos mantidos em pastagem cultivada de clima 
temperado e recebendo diferentes suplementos.

Ciência Rural, v. 36, n. 3, 2006.

http://dx.doi.org/10.1590/S0103-

84782006000300026

Slyter, L. L. Influence of acidosis on rumen function. Journal Animal Science, 43:910-929, 1976.

http://dx.doi.org/10.2527/jas1976.434910x

SIQUEIRA, G. B. Energia e Proteína na nutrição de ruminantes [livro eletrônico] Palmas: Universidade Federal do Tocantins, 2007.

Storm, E.; Ørskov, E. R. The nutritive value of rumen microorganisms in ruminants. 1. Large scale isolation and chemical composition of rumen micro-organisms. British Journal Nutrition, 50:463-470, 1983.

http://dx.doi.org/10.1079/BJN19830114

Strobel, H. L.; Russell, J. B. Effect of pH and energy spilling on bacterial protein synthesis by carbohydratelimited cultures of mixed rumen bacteria. Journal Dairy Science, v. 69, n. 11, p. 2941-2947, 1986.

http://dx.doi.org/10.3168/jds.S0022-

0302(86)80750-0

VALADARES FILHO, S. C.; PINA, D. S. Fermentação Ruminal. IN: BERCHIELLI et al. Nutrição de Ruminantes. Jaboticabal: Funep, 2011.
Van Soest, P. J. Nutrition ecology of ruminants. Ithaca. Cornell University Press, p. 476, 1994.

Wakabayashi, K. Changes in cell wall polysaccharides during fruit ripening. Journal Plant Research, v. 113, p. 231-237, 2000.

http://dx.doi.org/10.1007/PL00013932

Walter, M., Silva, L. P., Emanuelli, T. Amido resistente: características físico-químicas, propriedades fisiológicas e metodologias de quantificação. Ciência Rural, v. 35, n. 4, p. 974-980, 2005.

http://dx.doi.org/10.1590/S010384782005000400041

Wascheck, R. C. Pectina um carboidrato complexo e suas aplicações. Estudos, Goiânia, v. 35 , n. 3 , p. 343-355, 2008.

Williams, A. G. Rumen Holotrich Ciliate Protozoa. Microbiology Reviews. v. 50, n. 1, p. 25-49, 1986.

Zeoula, L. M.; Caldas Neto, S. F.; Branco, A. F.; Prado, I. N.; Dalponte, A. O.; Kassies, M.; Fregadolli, F. L. Mandioca e Resíduos das Farinheiras na Alimentação de Ruminantes: pH, Concentração de N-NH3 e Eficiência Microbiana. Revista Brasileira de Zootecnia, v. 31, n. 3, p. 1582-1593, 2002.

http://dx.doi.org/10.1590/S151635982002000600030 